> Tips om medisinsk litteratur, andre bøker, filmer og elektroniske medier som bør anmeldes, sendes tidsskriftet@legeforeningen.no

\section{Livet, døden og legerollen}

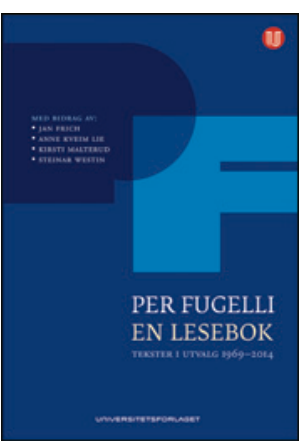

\author{
Per Fugelli
}

\section{En lesebok}

Tekster i utvalg 1969-2014. 576 s. Oslo:

Universitetsforlaget, 2014. Pris NOK 449

ISBN 978-82-15-02091-4
Universitetsforlaget har med denne boken ønsket å undersøke hvilke faglige og politiske avtrykk Per Fugelli har satt, gjennom å samle noen av hans mest betydningsfulle artikler og la fire fagfeller kommentere dem. Kirsti Malterud har fått ansvar for allmennmedisin, Steinar Westin for helsesamfunnet og fremmedfrykten, Anne Kveim Lie har ansvar for «himmelsyken», nok-punktet og livet, og Jan Frich har tatt ansvar for medisinen og døden. Boken er delt i fem deler: Allmennmedisinen - en kjærlighetserklæring, Politikk er intet annet enn medisin i stort, Tidens sykdommer er tidens sjel, Medisinen og døden og Siste kapittel.

Det er gjengitt $i$ alt 65 artikler, den tidligste fra 1969, den seneste fra utgivelsesåret. Hver av hoveddelene har et oppsummerende innledningskapittel med tittelen «I krystall». Delene avsluttes med fagfellenes kommentarartikler. Boken har fått tittelen En lesebok, inspirert av det engelske begrepet «reader».

Per Fugelli har virket i det offentlige rom siden tidlig i 1970årene. Han har blitt en folkekjær mann, en skattet og uredd debattant og en beundret lege. Denne boken oppsummerer hans livsverk.

Per Fugelli kommer fra Stavanger, hans far var lege, som hans far før ham. I sin tale til sine medstudenter ved studieavslutningen i 1969 sier Fugelli: «Vi vet at vi ikke er ferdige med noe som helst, aller minst det medisinske studium. Det varer livet ut, noe de fleste av oss er glade for.» I samme tale sier han om legens plikter: «1. Å være medmenneske, 2. Å være doktor sensu strictori». Gjennom sitt virke har han vært tro mot dette.

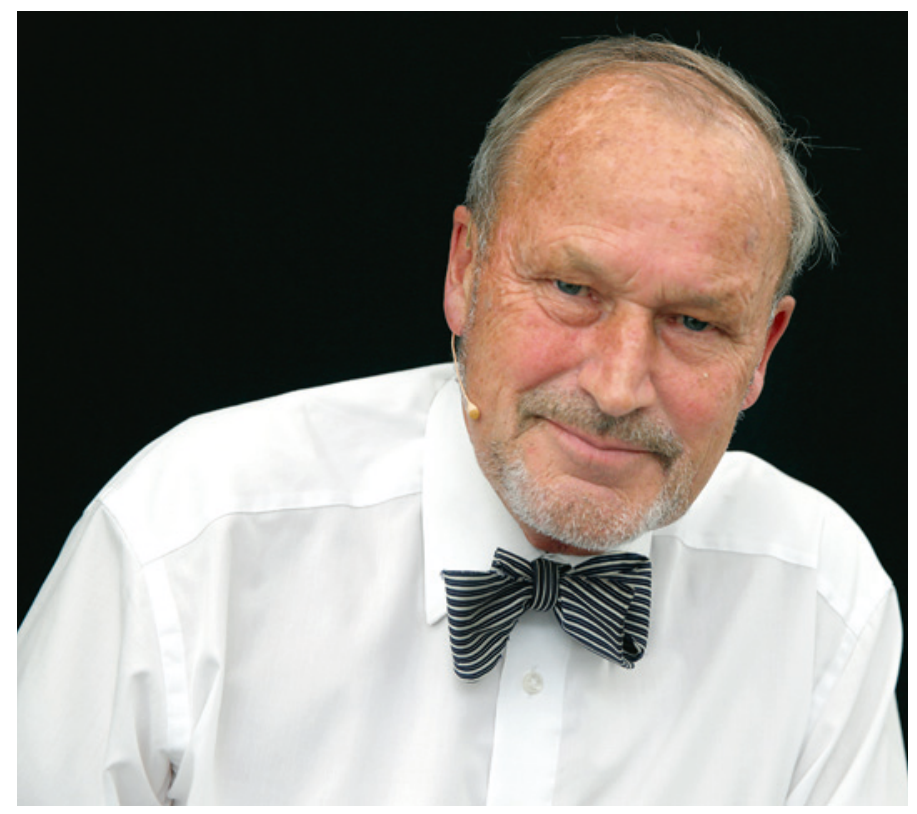

Per Fugelli. Foto: Berit Roald/Scanpix
Det går en bemerkelsesverdig tydelig tråd gjennom denne samlingen av arbeider fra et langt faglig liv. Fra hans tid som lege på Værøy og Røst og i Finnmark, fra hans sosialmedisinske arbeid, fra hans reiser i verden og fra hans tid som pasient med alvorlig diagnose. Nysgjerrigper er navnet han gir seg selv. Han har valgt legerollen som sitt studieobjekt. Hva er det som skjer mellom lege og pasient? Hva er det som gir legen den ønskede posisjonen? Hvordan kan denne posisjonen brukes? Fugelli tenker, spør, analyserer og finner svar. Han formulerer ønsker og krav. Han blir hørt. Fastlegeordningen er innført. Vi er blitt langt flere leger, samtidig som vi har fått langt mer kunnskap om de sykdomsskapende prosessene. Vel og bra, sier Fugelli, samtidig som han advarer mot den oppsplitting av fag og samtidig forståelse av pasienten som medmenneske dette medfører.

Per er professor, han forsker. Han leter ikke etter p-verdier eller oddsratio, han leter etter det gåtefulle som ikke er forskbart gjennom de metodene som er mest vanlige i medisinen. Han peker mot at kvalitativ forskning kanskje er veien å gå for å komme videre. Han gjør det nødvendige forarbeidet for kanskje å muliggjøre slik forskning når man vil forstå legens rolle stilt overfor den andre, den som er engstelig, den som har smerter, den som har fått en sykdom - eller kanskje ikke har fått en sykdom. Han peker på tillit og kontinuitet som viktige faktorer, som fagets gull.

Per er sint, han hamrer løs på myndigheter, på epidemiologer, på utviklingen innen medisinen der spesialisering gjør at man har kunnskap om et så lite felt at det er umulig å nå pasienten. Han peker strengt mot myndighetene som ikke ser enkeltmenneskets verdi, men bare peker på kostnader. Han raser mot Fremskrittspartiet som gjør livet for innvandrere umulig. Han latterliggjør psykiatriens stadig sterkere opptatthet av diagnoser.

Samtidig viser han til all klokskap han finner på Værøy og Røst der fant han begrepet blandingsmennesket. Alle mennesker er blandingsmennesker, sier Per, sterke noen ganger, svake i andre sammenhenger. Noen ganger står man fremme på scenen, men der finnes også et bakrom der andre sider kommer frem. Det er slik det er. På Værøy og Røst møter menneskene naturkreftene og vet at de er sterkere enn mennesket, der dyrkes ikke den sterkeste fordi alle vet at alle har både styrker og svakheter.

Men Fugelli vil mer. Vi skal åpne samfunnet, vi skal måles ut fra hvordan vi behandler våre svakeste. Vi skal kreve, og vi skal kjempe. Vi skal rette oss mot våre myndigheter og alle som vil bygge ned fellesskapsløsninger i samfunnet, og som vil fragmentere faget slik at ingenting lenger henger sammen.

Er han forsker eller politiker? Han er forsker, og han setter sitt arbeid inn i en politisk ramme. Ordføreren er like viktig som fastlegen for helsa, sier han, og i neste øyeblikk latterliggjør han folkehelsearbeid som griper inn i folks frihet. Ulogisk? Nei, faktisk ikke. Per søker frihet for enkeltmenneskene, samtidig som han påpeker viktigheten av offentlige regulering av menneskelig aktivitet, som i arbeidsmiljøloven eller folketrygden. 
Siden 2009 har Fugelli hatt en alvorlig kreftsykdom. Han har beskrevet dette i de to bøkene Døden, skal vi danse? og Journalen. Flere av artiklene er hentet fra disse bøkene. Her høster han av sin egen erfaring med møtet med helsevesenet, og han finner en viktig mangel - han savner den legen han får møte mer enn én gang, den legen han får tillit til, og som kjenner ham og hans lidelse. Dette blir en kampsak; slik han en gang kjempet for allmennlegen, kjemper han nå for at alvorlig syke skal ha sin fastlege i sykehus. Denne kampen har vunnet stor gjenklang blant folk. Nok en gang har han løftet en problemstilling, og han gjør som han prediker, han danner en allianse med summen av pasientene - som til sammen utgjør folket.

Alvorlig sykdom er uløselig knyttet til død - heller ikke dette temaet unngår Nysgjerrigper. Med samme undring som han har nærmet seg det ubeskrevne i lege-pasient-forholdet, nærmer han seg døden. Han bruker sine erfaringer fra sine reiser til andre kulturer så vel som fra lesing av Kirkeblad for Vaerøy og Røst. Han leter etter lyspunkter - og han finner dem.

Dette er en lesebok, «a reader» ville man sagt på engelsk. Fire fagfeller er bedt om å kommentere artikler innenfor hvert sitt felt. Dette fungerer godt. Det gir perspektiver på de arbeidene vi møter, og på Fugellis arbeid for øvrig. Malterud beskriver ham som en fagkritisk vekkelsespredikant, Westin diskuterer begrepet den politiske legen, Kveim Lie studerer en danser med og mot tidsånder, og Frich beskriver en vokter av medisinens grunnstoff. Disse blikkene gir fylde til Fugellis store prosjekt.

Det er et imponerende arbeid Fugelli legger frem i denne boken, imponerende fordi han har vært produktiv, imponerende fordi han prøver å finne og belyse en side av legekunsten som er vanskelig å forstå og enda vanskeligere å beskrive. Han viser hvordan medisinmannen i Kalahari utøver sin behandling basert på samme verdier som ham selv, til tross for at deres medisinske utgangskunnskap ikke er sammenliknbart.

Per Fugelli skriver godt, han har et lekende språk, han skaper ord der vi trenger nye, og han skaper ord fordi de er morsomme. Det gjør artiklene mer leseverdige, av og til blir denne lekende og lette språkføringen så god at man helt mister evnen til å vurdere hva han skriver om.

Under lesingen av alle disse artiklene har jeg av og til følt meg druknet i ord, jeg har stoppet, etterlyst substansen inne i språket, hver eneste gang har jeg konkludert med at her nærmer Per seg det ugjennomtrengelige, samtidig som han fortsetter å prøve.

Jeg er født på Værøy, mitt felt innen medisinen har vært sosialpsykiatri, jeg har vært aktiv politiker på flere nivåer, jeg lider av samme alvorlige sykdom som Per. Dette gir meg særlig viktige ståsteder når jeg skal vurdere denne leseboken. Hans prosjekt kan være vanskelig å fange, hans fantastiske språk kan forføre, men å lese hans artikler er gledesfylt arbeid, det berører, det fremkaller latter, og av og til hoderisting. Boken er nyttig for enhver lege og for mange, mange andre.

Guri H. Ingebrigtsen

Overlege, Senter for psykisk helsevern - Lofoten Nordlandssykehuset

\section{Far og sønn}

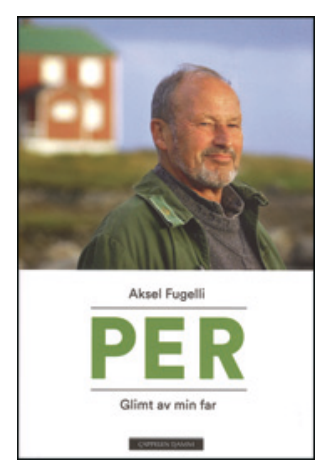

Aksel Fugelli

Per

Glimt av min far. 247 s, ill. Oslo: Cappelen

Damm, 2014. Pris NOK 349

ISBN 978-82-02-42298-1

Dette er en biografi om Per (utelatelsen av etternavnet i bokens tittel er berettiget). Biografen er Pers sønn. Skildringen blir således preget av en tydelig nærhet mellom den som portretterer, og den som portretteres.

Boken er oppdelt i korte essay, som ikke er kronologisk, men tematisk strukturert. Lesingen flytter oss dermed frem og tilbake i tid, mellom tidlig barndom og nåtid. Dette skjer på en måte som gjør lesingen mer spennende. Hovedtemaet er Per og hans liv og virke. Stoffet er oppdelt i hans virksomheter som fagmann, samfunnsengasjert menneske og far, men det er likevel hele tiden tydelig hvordan hans ulike roller er tett sammenvevd og gjensidig avhengig av hverandre. Det er mange måter å klassifisere en boks tema på, men det er en mye vanskeligere oppgave i en bok som omhandler livet, døden, kjærligheten, far-sønn-relasjonen, familien, naturen, den rurale nordlending og mye mer. Forfatteren selv deler boken i tre deler - hvem er du, hva har du gjort, og hva vil du?

De fleste essayene har en dialogisk form preget av åpenhet, ærlighet og nysgjerrighet. Vi får gjengitt lange samtaler mellom far og sønn i detalj. Dette litterære grepet levendegjør stoffet på en måte som virker engasjerende på leseren, og det gjør dynamikken i samtalene tydelig. Spørsmålene intervjueren stiller, er til dels provokatoriske, og av og til får de sin tilsiktede virkning. Han som intervjues, har et bevisst forhold til de mer eller mindre utematiserte forutsetningene som spørsmålene bygger på, og ofte går han løs på disse i stedet for på selve spørsmålet («du blander kortene» og «du er på feil sted»). Av og til innebærer dette at intervjueren får tilbake et spørsmål i stedet for et svar (hva er virkelighet?). Igjen, dette øker spenningsnivået hos leseren, og det blir vanskelig å legge bort boken før vi har sett hvordan det hele ender.

For en sosiolog er det to elementer i dialogene mellom far og sønn som er særlig interessante: Sønnen (intervjueren) er på jakt etter sannheter om hvordan noe egentlig var og er. Faren, på sin side, tror ikke at en slik sannhet finnes. Sønnen har også et ønske om å forstå sin far gjennom å finne forklaringer på «hva» og «hvorfor» i farens liv, noe faren ikke har spesielt sans for. Per vil, forståelig nok, ikke bli forklart. Han bare er sånn. Sønnen er ikke alltid like lydhør overfor farens motstand mot å bli forklart, men som en annen ordmester (Dylan) ville sagt det: «Your sons and your daughters are beyond your command».

\section{Olaug S. Lian}

Professor, Universitetet i Tromsø 